\title{
PERBEDAAN PIJAT DAN SPA BAYI TERHADAP POLA TIDUR DAN PENINGKATAN BERAT BADAN PADA BAYI USIA 3-5 BULAN
}

\author{
Shinta Utami1), Kusnandi Rusmil2), Uni Gamayani3) \\ ${ }^{1}$ Dosen Prodi D III Kebidanan Stikes Sukabumi \\ 2Departemen IImu Kesehatan anak, Fakultas Kedokteran Universitas Padjadjaran \\ ${ }^{3}$ Departemen Neurologi Fakultas Kedokteran Universitas Padjadjaran \\ 1email: Sabilnde02@gmail.com \\ 2email:kusnandi@hotmail.com \\ ${ }^{3}$ email:gumayani@yahoo.com
}

\begin{abstract}
Background Baby massage is a kind of useful stimulation for improving sleep rhythm and gaining weight. Nowadays, baby spa phenomenon become trend, and the treatments are massage and hydrotherapy. There is a lack of evidence of baby spa's benefit and mostly it was a pilot study with minimum research subject.

Purposeof this study is to analyze the difference between baby massage and baby spa for sleep rhythm and weight gain for 3 to 5 months old babies.

Methods The design of this study was pre test and post test quasi experimental. The study was conducted at Dinas Kesehatan area of Sukabumi in a two places separately, for baby massage group, it's conducted at Puskesmas Baros and for baby spa group it's conducted at Irna Klinik, on October to December, 2017. It used consecutive sampling, it took 58 respondents, 30 respondents for baby massage group and 28 respondents for baby spa group. The body weight was measured by using a digital scale and the measurement result was weight in gram scale, whereas the sleeping scheme was carried out by interview method using questionnaire brief infant sleep questionnaire (BISQ) by measuring the duration of sleep in hours. This study used unpaired T-test and Mann Whitney for bivariate analysis.

Result showed that sleep rhythm mean for baby massage group (1.8 hours) was longer than baby spa group (1.5 hours), but there's no differences between two groups significantly with $p$ value $=0.229$. The weight gain mean for baby massage group $(0.89 \mathrm{~kg})$ was higher than baby spa group $(0.64 \mathrm{~kg})$ and it had a significant diffeences with $p$ value $=0.000$.

Conclusion of this study is there was a different impact for baby massage and baby spa to improve babies weight on 3 to 5 months old. There's no differences of baby massage and baby spa's impact for sleep rhythm for 3 to 5 months old babies.
\end{abstract}

Sugestion Further research is needed on the provision of baby SPA accompanied by regular infant massages

Key words : Baby spa, Massage, Sleep rhythm, Weight gain

\section{ABSTRAK}

Latar Belakang Pijat bayi merupakan bentuk stimulasi yang bermanfaat untuk memperbaiki pola tidur dan meningkatkan berat badan. Saat ini sedang marak fenomena mengenai Spa bayi. Bukti ilmiah mengenai manfaat Spa bayi masih sedikit.

Tujuan dari penelitian ini untuk menganalisis perbedaan pijat dan Spa bayi terhadap pola tidur dan penambahan berat badan pada bayi usia 3-5 bulan.

Metode Penelitian ini menggunakan quasi eksperimen dengan desain pre and postest. Penelitian ini dilakukan di kota Sukabumi pada dua tempat terpisah yaitu di Puskesmas Baros dan Klinik Irna, pada bulan Oktober - Desember 2017. Pengambilan sampel dilakukan dengan cara Consecutive Sampling, sampel yang digunakan sebanyak 30 responden untuk pijat bayi dan 28 responden untuk Spa bayi. Untuk berat badan di ukur menggunakan timbangan digital dan hasil ukurnya adalah berat badan dalam gram sedangkan untuk pola tidur dilakukan metode wawancara menggunakan kuesioner Brief Infant Sleep Quetionnaire (BISQ) dengan hasil ukur lama tidur dalam jam.. Analisis bivariat yang digunakan pada penelitian yaitu uji t tidak berpasangan dan uji Mann-Whitney.

Hasil penelitian menunjukan bahwa nilai rata-rata pola tidur pada pijat bayi lebih besar di bandingkan dengan kelompok Spa bayi, tetapi tidak terdapat perbedaan yang signifikan antar kedua kelompok dengan nilai 
$p=0$,229. Penambahan rata-rata berat badan pada kelompok pijat lebih besar dan Spa bayi serta terdapat perbedaan yang signifikan antar kedua kelompok dengan nilai $p=0,000$.

KesimpulanTerdapat perbedaan pengaruh pijat dan Spa bayi terhadap peningkatan berat badan. Tidak terdapat perbedaan pengaruh pijat dan Spa bayi terhadap pola tidur.

Saran Diperlukan penelitian lebih lanjut tentang pemberian SPA bayi yang dibarengi pijat bayi yang dilakukan secara teratur

Kata Kunci : Pijat, Spa bayi, Pola tidur, Berat badan.

\section{PENDAHULUAN}

Seribu hari pertama kehidupan adalah masa keemasan sekaligus masa kritis perkembangan anak. Masa kritis bayi terhadap lingkungan ini dapat mengakibatkan adanya gangguan tumbuh kembang diantaranya karena adanya gangguan tidur dan berat badan yang kurang. Agar bayi mencapai pertumbuhan dan perkembangan yang optimal salah satunya diperlukan stimulasi. Pijat bayi merupakan salah satu bentuk stimulasi yang bermanfaat bagi tumbuh kembang (Soetjiningsih, UKK Tumbuh Kembang Pedsos, 2013) Pijat bayi dapat memperbaiki pola tidur dan juga dapat meningkatkan berat badan (Ferber SG, 2002. Bennett C 2013).

Saat ini banyak salon SPA khusus bayi bermunculan di mana salah satu perawatannya adalah pijat bayi. SPA singkatan dari Sehat Pakai Air, penggunaan air di dunia kesehatan konvensional dikenal dengan istilah hidroterapi medik. Hidroterapi ditujukan untuk meningkatkan kualitas kesehatan dan kebugaran. SPA tidak semata-mata mencakup hidroterapi saja, tetapi juga mencakup perawatan lain, seperti pemijatan tubuh (Kemenkes RI, 2014). Di tempat SPA pijat bayi dilakukan oleh terapis sehingga harus megeluarkan biaya untuk perawatan SPA bayi. Pijat bayi ini sebaiknya dilakukan oleh ibu karena pijat adalah salah satu cara termudah dan paling alami untuk membangun rasa kontak sentuhan dan mata yang meningkatkan keterikatan antara ibu dan bayi (Gurol A, 212).

Apabila perawatan pijat bayi dilakukan oleh ibu akan lebih ekonomis dan efisien. Pijat bayi dapat terlihat manfaat nya apabila rutin dilakukan selama 4 minggu. Telah ditunjukkan bahwa pijatan yang dilakukan ibu sama efektifnya dengan terapis terlatih (Jabraeile, M et al, 2106. Ferber SG et al ,2002) Tetapi saat ini penelitian SPA bayi masih sedikit dan merupakan studi pendahuluan dengan sampel yang minim.

Usia 3-5 bulan merupakan usia tepat bagi bayi mulai melakukan SPA bayi karena Pada usia 3-5 bulan kontrol leher sudah baik sehingga kepala bayi dapat tegak dan berat badan bayi mencapai 2 kali berat badan lahirnya. Selain itu pada usia ini juga bayi sering rewel yang dapat menyebabkan gangguan tidur.(Kusmini dkk, 2015. IDAI ,2013). Tujuan penelitian ini untuk menganalisis perbedaan pijat dan SPA bayi terhadap pola tidur dan peningkatan berat badan pada bayi usia 3-5 bulan.

\section{METODE PENELITIAN}

Penelitian ini menggunakan quasi eksperimen dengan desain pre and postest. dilakukan di wilayah kerja Dinas Kesehatan kota Sukabumi di dua tempat terpisah, untuk kelompok pijat bayi dilakukan di Puskesmas Baros dan kelompok SPA bayi dilakukan di Klinik Irna, pada bulan Oktober - Desember 2017. Pengambilan sampel dilakukan dengan cara Consecutive Sampling. Sampel yang digunakan adalah 58 responden, 30 responden untuk kelompok pijat bayi dan 28 responden untuk kelompok SPA bayi. Kelompok pijat perlakuan diberikan pijat kepada bayi oleh ibu setiap hari selama 4 minggu, sedangkan untuk kelompok SPA bayi perlakuan di berikan SPA bayi oleh terapis setiap 1 minggu sekali selama 4 minggu. Analisis bivariat yang digunakan pada penelitian yaitu uji $t$ tidak berpasangan dan uji Mann- Whitney.

\section{HASIL DAN PEMBAHASAN}

Data penelitian sebelum dianalisis terlebih dahulu dilakukan uji normalitas data dengan tujuan untuk mengetahui apakah data berdistribusi normal atau tidak. Pengujian normalitas data meggunakan Shapiro-Wilk. Hasil uji normalitas pada pola tidur sebelum dan sesudah intervensi serta pola tidur pada kedua kelompok berdistribusi tidak normal. Sedangkan untuk berat badan sebelum dan sesudah perlakuan serta peningkatan berat badan berdistribusi normal. Hasil penelitian selengkapnya diuraikan sebagai berikut :

Data perbedaan karakteristik bayi dan ibu pada kelompok penelitian dapat dilihat pada tabel 1 di bawah ini 
Tabel 1 Perbedaan karakteristik bayi dan ibu pada kedua kelompok

\begin{tabular}{lccc}
\hline Karakteristik & \multicolumn{3}{c}{ Kelompok } \\
\hline & $\begin{array}{c}\text { Pijat Bayi } \\
\mathrm{n}=30\end{array}$ & $\begin{array}{c}\text { SPA Bayi } \\
\mathrm{n}=28\end{array}$ & Nilai P \\
\hline $\begin{array}{c}\text { Jenis kelamin } \\
\text { Laki-laki }\end{array}$ & $17(56,7 \%)$ & $13(46,4 \%)$ & $0,436^{*}$ \\
$\begin{array}{l}\text { Perempuan } \\
\text { Usia bayi }\end{array}$ & $13(43,7 \%)$ & $15(53,6 \%)$ & \\
$2 \quad$ Bulan & $11(36,7 \%)$ & $14(50 \%)$ & $0,855^{*}$ \\
$3 \quad$ Bulan & $11(36,7 \%)$ & $11(39,3 \%)$ & \\
$4 \quad$ Bulan & $8(26,6 \%)$ & $3(10,7 \%)$ & \\
$\begin{array}{c}\text { Pendidikan ibu } \\
\text { SD }\end{array}$ & $4(13,3 \%)$ & $0(0 \%)$ & \\
SMP & $11(36,7 \%)$ & $0(0 \%)$ & $0,001^{*}$ \\
SMA & $11(36,7 \%)$ & $10(35,7 \%)$ & \\
Perguruan Tinggi & $4(13,3 \%)$ & $18(64,3 \%)$ & \\
Pekerjaan ibu & & & \\
Bekerja & $8(26,7 \%)$ & $9(32,1 \%)$ & $0,647^{*}$ \\
IRT & $22(73,3 \%)$ & $19(57,9 \%)$ & \\
\hline
\end{tabular}

Berdasarkan tabel 1 diatas dapat diketahui bahwa pada kelompok pijat bayi sebagian besar adalah berjenis kelamin laki-laki (56,7\%), usia 3-4 bulan $(36,7 \%)$, pendidikan ibu SMP dan SMA $(36,7 \%)$ dan ibu merupakan ibu rumah tangga $(73,3 \%)$. Sedangkan untuk kelompok SPA bayi sebagian besar berjenis kelamin perempuan
(53,6\%), usia bayi 3 bulan

(50\%), pendidikan ibu perguruan tinggi $(64,3 \%)$, dan ibu rumah tangga $(57,9 \%)$, tidak terdapat perbedaan antara jenis kelamin, usia bayi dan pekerjaan ibu terhadap kedua kelompok, sedangkan terdapat perbedaan pendidikan antara kelompok pijat dan SPA bayi.

Tabel 2 Gambaran Karakteristik Tidur Bayi

\begin{tabular}{lcc}
\hline \multicolumn{1}{c}{ Karakteristik Tidur bayi } & \multicolumn{2}{c}{ Kelompok } \\
\cline { 2 - 3 } & $\begin{array}{c}\text { Pijat Bayi } \\
(\mathrm{n}=30)\end{array}$ & $\begin{array}{c}\text { SPA Bayi } \\
(\mathrm{n}=28)\end{array}$ \\
\hline Pengaturan tidur , $\mathrm{n}(\%)$ & $0(0)$ & $0(0)$ \\
Di kamar yang terpisah & $0(0)$ & $5(17,9)$ \\
Di tempat tidurnya sendiri & $0(0)$ & $0(0)$ \\
Di dalam kamar orang tua & $30(100)$ & $23(82,1)$ \\
Satu tempat tidur dengan orangtua & $0(0)$ & $0(0)$ \\
Di tempat tidurnya sendiri satu ruangan dengan saudara & & \\
kandung lain & & \\
Posisi Tidur, $\mathrm{n}(\%)$ & $4(13,3)$ & $5(17,9)$ \\
Tengkurap & $12(40)$ & $7(25)$ \\
Miring & $14(46,7)$ & $16(57,1)$ \\
Terlentang & & \\
Cara jatuh tertidur, $\mathrm{n}$ (\%) & $27(90)$ & $22(78,6)$ \\
Tertidur ketika disusui & $3(10)$ & $0(0)$ \\
Tertidur ketika sendirian ditempat tidur & $0(0)$ & $6(21,4)$ \\
Tertidur ketika diayun &
\end{tabular}




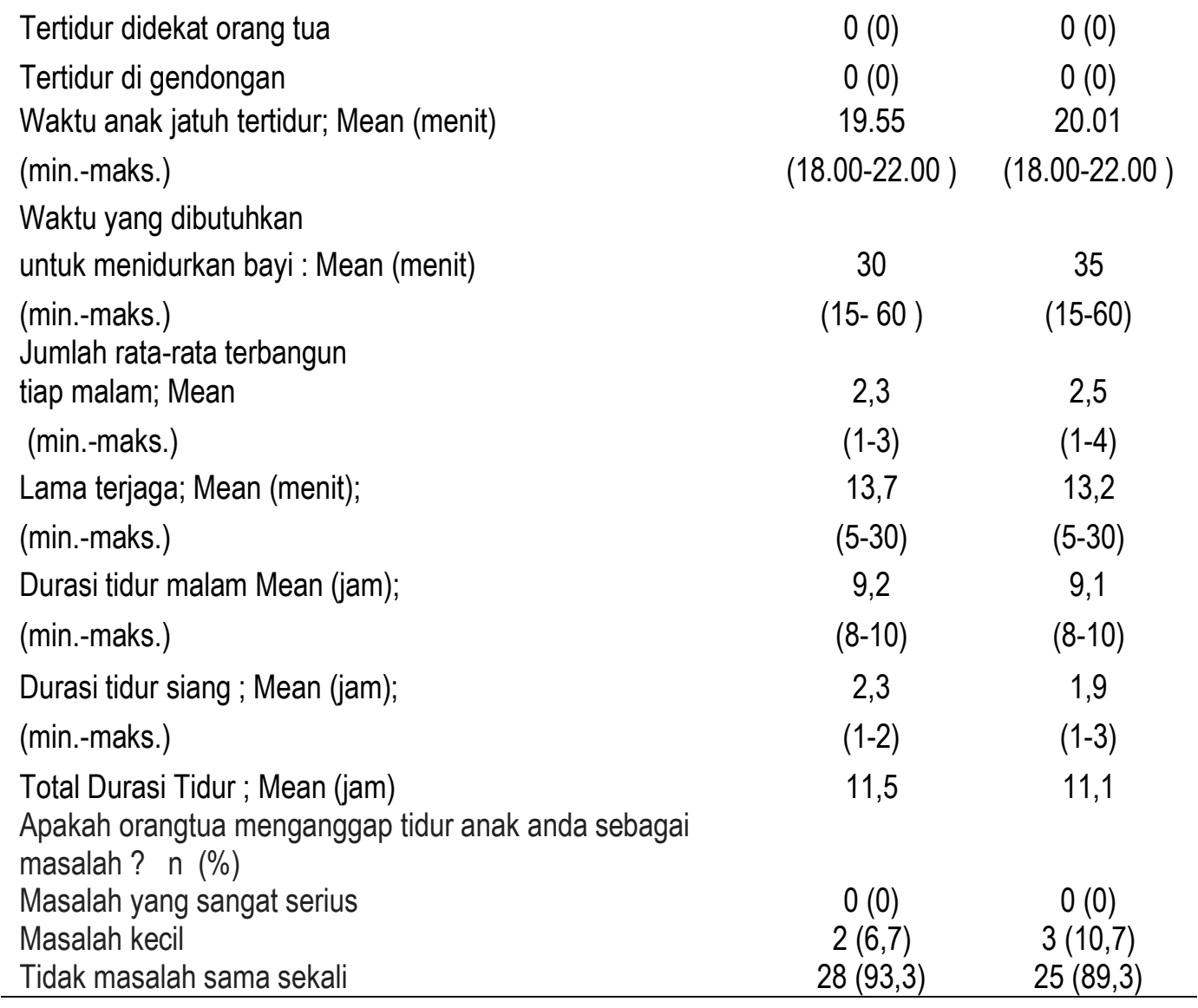

Berdasarkan tabel 2 Pada kelompok pijat bayi semua bayi $(100 \%)$ tidur satu tempat tidur dengan orangtua, posisi tidur terlentang $(46,7 \%)$, tertidur ketika disusui (90\%), waktu anak jatuh tertidur pukul 19.55 menit, waktu untuk menidurkan bayi 30 menit, rata-rata terbangun tiap malam 2,3 kali, lama terjaga 13,7 menit, total durasi tidur 11,5 jam dan menganggap tidur anak tidak bermasalah sama sekali $(93,3 \%)$ sedangkan pada kelompok
SPA bayi, sebagian besar bayi tidur bersama orangtua $(82,1 \%)$, posisi tidur terlentang $(57,1 \%)$, tertidur ketika disusui $(78,6 \%)$, waktu anak jatuh tertidur pukul 20.01 menit, waktu untuk menidurkan bayi rata- rata 35 menit, Jumlah rata-rata terbangun tiap malam 2,5 kali, lama terjaga 13,2 menit, total durasi tidur 11,2 jam dan meganggap tidur anak tidak bermasalah sama sekali $(89,3 \%$.

Tabel 3 Perbedaan Pijat dan SPA Bayi Terhadap Pola Tidur serta Berat badan Sebelum dan Sesudah Perlakuan

\begin{tabular}{cccc}
\hline Kelompok & & Nilai p \\
\hline & $\begin{array}{c}\text { Sebelum } \\
\text { Mean,SD (jam) }\end{array}$ & $\begin{array}{c}\text { Sesudah } \\
\text { Mean,SD (jam) }\end{array}$ & \\
\hline Pola Tidur & & & \\
Pijat bayi & $11,60(0,99)$ & $13,43(0,62)$ & $0,000^{*}$ \\
SPA bayi & $10,85(0,90)$ & $12,35(0,73)$ & $0,000^{*}$ \\
Berat Badan & & & \\
Pijat bayi & $6,75(0,73)$ & $7,64(0,70)$ & $0,000^{* *}$ \\
SPA bayi & $6,30(0,59)$ & $6,94(0,54)$ & $0,000^{* *}$ \\
\hline Data tidak normal : *Uji Wilcoxon & & \\
Data Normal : ${ }^{*}$ Uji T berpasangan & &
\end{tabular}

Berdasarkan tabel 3 dapat diketahui bahwa terdapat perbedaan yang bermakna antara kelompok pijat dan SPA bayi terhadap pola tidur dan berat badan sebelum dan sesudah perlakuan 
Tabel 4 Perbedaan Pola Tidur Pada Kelompok Pijat dan SPA Bayi

\begin{tabular}{ccccc}
\hline Pola tidur & \multicolumn{4}{c}{ Median (jam) } \\
\hline & $\mathrm{n}$ & Rerata (jam) & $p$ \\
\hline Pijat Bayi & 30 & $2.00(0,00-4,00)$ & 1,83 & 0,229 \\
SPA bayi & 28 & $1,75(0,00-4,00)$ & 1,50 & \\
\hline Data tidak normal : uji Mann Whitney &
\end{tabular}

Berdasarkan tabel 4 didapatkan tidak terdapat perbedaan yang bermakna antar kedua kelompok tetapi rata-rata penambahan pola tidur pada kelompok pijat lebih besar dibandingkan dengan SPA bayi, pada kelompok pijat 1,83 jam dan pada kelompok SPA bayi 1,50 jam.

Tabel 5 Perbedaan Peningkatan Berat Badan Pada Kelompok Pijat dan SPA Bayi

\begin{tabular}{ccccc}
\hline Kelompok & \multicolumn{4}{c}{ Peningkatan berat badan } \\
\hline & $\mathrm{n}$ & Rerata $(\mathrm{kg})$ & Perbedaan Rerata $\mathrm{Cl} 95 \%$ & $\mathrm{p}$ \\
\hline Pijat Bayi & 30 & $0,88(0,22)$ & $0,24(0,34-0,13)$ & 0,000 \\
SPA bayi & 28 & $0,64(0,14)$ & & \\
Data normal : uji t tidak berpasangan.
\end{tabular}

Berdasarkan tabel 5 terdapat perbedaan yang signifikan antara kelompok pijat dan SPA bayi terhadap peningkatan berat badan, dengan nilai rata-rata kelompok pijat lebih tinggi dari pada kelompok SPA bayi. Pada kelompok pijat penambahan berat badan rata-rata $0,88 \mathrm{~kg}$ sedangkan pada kelompok SPA bayi 0,64 .

\section{Perbedaan Karakteristik bayi dan ibu}

Pada kelompok pijat bayi sebagian besar berjenis kelamin laki-laki $(56,7 \%)$, sedangkan pada kelompok SPA bayi sebagian besar berjenis kelamin perempuan $(53,6 \%)$. Menurut Scher tidak terdapat perbedaan bermakna antara pola tidur dengan jenis kelamin anak perempuan dan laki-laki. Berbeda dengan kurva pertumbuhan berat badan pada bayi laki-laki lebih besar dibandingkan dengan bayi perempuan. (Wulandari A. 2007)

Usia bayi pada kelompok pijat bayi sebagian besar berusia 3-4 bulan (36,7\%) sedangkan untuk kelompok SPA bayi sebagian besar berusia 3 bulan $(50 \%)$. Seiring dengan bertambahnya usia maka penambahan jam tidur serta berat badan akan berkurang. Pada usia 3-5 bulan rata-rata kenaikan berat badan adalah 500 -600 gram perbulan dan bayi masih sering rewel sehingga sering terjadi gangguan tidur. (Soetjiningsih. 2013)

Pada pendidikan ibu terdapat perbedaan yang bermakna antara kelompok pijat dan SPA bayi. Untuk kelompok pijat bayi pendidikan ibu sebagian besar SMA dan SMP $(36,7 \%)$, sedangkan untuk kelompok SPA bayi sebagian besar perguruan tinggi (64,3\%). Menurut penelitian Devinta terdapat hubungan antara tingkat pendidikan dengan perilaku konsumtif. Perilaku ini didorong karena terdapat sarana promosi penjualan, lingkungan fisik, dan tekanan ekonomi. Saat ini sedang marak fenomena SPA (Sehat Pakai Air) khusus bayi sejak beberapa tahun kebelakang. Berbagai aktivitas menarik, baik untuk bayi maupun ibu gencar ditawarkan, sehingga mendorong ibu terutama yang berpenidikan tinggi membawa bayinya mengikuti perawatan SPA. (Gunardi $\mathrm{H}$. 2015)

Pijat dan SPA bayi merupakan salah satu bentuk stimulasi untuk mengoptimalkan pertumbuhan dan perkembangan anak. Menurut penelitian Aluisio JD Barros dkk di Brazil anak-anak yang mendapatkan stimulasi perkembangan nilai perkembangannya lebih baik pada ibu yang pendidikan lebih rendah (Barros AJ, 2010). Hal ini menunjukkan keberhasilan suatu stimulasi tidak tergantung dari pendidikan orangtua tetapi lebih ditentukan oleh efektifitas dan kesinambungan stimulasi pada anak.(Ringwalt S. 2008).

Pada penelitian ini untuk kelompok pijat bayi sebagian besar merupakan ibu rumah tangga $(73,3 \%)$, sedangkan untuk kelompok SPA bayi 
merupakan ibu bekerja (57,9\%). Menurut penelitian Dixy di Yogyakarta tidak terdapat hubungan yang bermakna antara profesi ibu dengan pemberian stimulus pada anak. (Dixy F,2012)

Hasil tersebut sesuai dengan penelitian Dewi di Surabaya yang menyatakan bahwa tidak terdapat perbedaan kualitas stimulasi ibu di lingkungan rumah pada usia anak pra sekolah ditinjau dari status bekerja dan tidak bekerja.(Dewi, K.A. 2010)

Bayi yang mendapat stimulasi yang terarah akan lebih cepat berkembang dibandingkan bayi yang kurang bahkan tidak mendapat stimulasi (Soetjiningsih,2013). Adapun faktor-faktor yang mempengaruhi perkembangan anak yaitu faktor internal dan faktor eksternal, faktor internal meliputi genetik dan pengaruh hormon sedangkan faktor eksternal meliputi lingkungan. Orang tua termasuk dalam faktor lingkungan, yaitu lingkungan keluarga karena disinilah orang tua melakukan interaksi pertama kali dengan bayi untuk mengembangkan kemampuan bayi sesuai dengan usia perkembangannya. (Kemenkes RI. 2012)

Interaksi yang dapat memaksimalkan perkembangan bayi bukan dilihat dari kuantitas (seberapa lama kita bersama bayi) melainkan kualitas interaksi tersebut, sehingga bisa saja seorang ibu yang bekerja dan hanya memiliki waktu sedikit dengan bayinya mempunyai bayi dengan perkembangan lebih baik dari pada ibu rumah tangga yang fisiknya selalu ada di rumah, asalkan ibu yang bekerja tadi bisa lebih pintar mengolah waktu yang sedikit tersebut menjadi berkualitas. (Dixy F,2012)

\section{Gambaran Karakteristik Tidur Bayi}

Gambaran pola tidur pada kelompok pijat dan SPA bayi menunjukkan rata-rata jumlah jam tidur kurang dari seharusnya untuk kelompok pijat bayi 11,5 jam dan untuk kelompok SPA bayi 11,2 jam. Jumlah jam tidur yang ideal untuk menjamin pertumbuhan bayi secara optimal pada usia 11 bulan adalah antara 12 - 16 jam perhari. (Paruthi, et al. 2016)

Tidur adalah suatu proses yang sangat penting bagi manusia, karena dalam tidur terjadi proses pemulihan, proses ini bermanfaat mengembalikan kondisi seseorang pada keadaan semula, dengan begitu tubuh yang tadinya mengalami kelelahan akan menjadi segar kembali. Proses pemulihan yang terhambat dapat menyebabkan organ tubuh tidak bisa bekerja dengan maksimal, akibatnya orang yang kurang tidur akan cepat lelah dan mengalami penurunan konsentrasi. (UKK Tumbuh Kembang Pedsos.2013)

Kualitas tidur adalah mutu atau keadaan fisiologis tertentu yang didapatkan selama seseorang tidur, yang memulihkan proses- proses tubuh yang terjadi pada waktu orang itu bangun. Jika kualitas tidurnya bagus artinya fisiologi tubuh dalam hal ini sel otak pulih kembali seperti semula saat bangun tidur (Sekartini R. 2015).

Kualitas tidur yang baik ditunjukan dengan jumlah jam tidur bayi yang cukup, bayi dapat jatuh tertidur dengan mudah di malam hari, bugar saat bangun tidur, dan tidak rewel. Kualitas tidur yang buruk selain ditunjukkan oleh jumlah jam tidur yang kurang dari kebutuhan sesuai umur juga ditunjukkan oleh adanya gangguan-gangguan selama tidur antara lain sering terbangun di malam hari dan waktu terjaga yang lebih dari 30 menit setiap kali terbangun.(Sadeh A. 2004)

Pada penelitian ini semua bayi diberikan ASI eksklusif, pada bayi dengan ASI esklusif ratarata frekuensi menyusui malam hari adalah 1-3 kali sehingga lebih sering terbangun. Tetapi hal ini normal karena pengosongan lambung pada bayi dengan ASI lebih cepat dibandingkan dengan susu formula. ASI dalam lambung bayi akan kosong dalam waktu sekitar 2-3 jam (AAP.2005). Pada pemberian ASI eksklusif juga bayi yang normal dan sehat dapat mengosongkan satu payudara sekitar 10-30 menit. Apabila lebih dari 30 menit maka perlekatan bayi perlu dicek, mungkin teknik menyusui ibu kurang tepat sehingga ASI yang keluar sangat sedikit sehingga bayi sulit merasa puas. Hal ini juga dapat megganggu tidur bayi karena akan lebih lama terjaga.(AAP. 2012. Roth, DE. 2010.)

Pada bayi yang kurang tidur seringkali menjadi suatu masalah sehingga mengganggu pertumbuhan bayi. Hal ini sebagaimana penelitian Whittingham \& Douglas yang mengemukakan antara $23 \%$ hingga $27 \%$ dari orang tua melaporkan masalah tidur bayi di 6 bulan pertama kehidupannya. (Whittingham. 2014). Sejalan dengan penelitian Falah di Semarang, Hampir semua ibu $(95,2 \%)$ batita dengan gangguan tidur tidak menyadari bahwa tidur anaknya bermasalah. (Faniyah Falah. 2015). Sementara itu sebagian besar para ibu pada penelitian ini pada kelompok pijat $(93,3 \%)$ maupun SPA bayi $(89,3 \%)$ menganggap tidur bayi tidak bermasalah sama sekali. Hal ini menunjukkan kesadaran orang tua mengenai gangguan tidur yang masih rendah. Hal ini sesuai dengan yang dilaporkan oleh Sadeh et al. (Wulandari A. 2007)

\section{Perbedaan Pijat dan SPA Bayi Terhadap Pola Tidur}

Tidak terdapat perbedaan yang signifikan 
antara pola tidur kelompok pijat dan SPA bayi,dalam tindakannya pijat bayi merupakan bagian dari perawatan SPA bayi. Kegiatan SPA bayi meliputi pijat dan hidroterapi. Pada kelompok SPA bayi dilakukan hidroterapi yang meliputi gerakan/latihan saat berada di dalam air yang suhu lebih hangat dari pada suhu air di kolam renang biasa yaitu antara $35-36^{\circ} \mathrm{C}$. (ARUK. 2017)

SPA merupakan salah satu terapi air, Penelitian pada bayi prematur yang mendapat terapi air selama 10 menit memperlihatkan bayi memperoleh terapi air kualitas tidurnya lebih baik, cenderung lebih rileks dan lebih dapat mentolerir nyeri. (Vignochi CM, Teixeira PP, Nader SS. 2010)

Pada kelompok SPA bayi perlakuan dilakukan oleh terapi sedangkan pada kelompok pijat bayi perlakuan dilakukan oleh ibu. Pijatan bisa diberikan oleh tenaga profesional terlatih atau oleh ibu. Telah ditunjukkan bahwa efektifitas pijat bayi yang dilakukan oleh ibu sama efektifnya dengan yang dilakukan oleh profesional serta pijat bayi yang dilakukan oleh ibu meminimalisir pengeluaran biaya. (Ferber SG, et al. 2002. Field. $\mathrm{T}, 2017)$ Pijat bayi yang dilakukan oleh ibu akan lebih banyak mendekatkan interaksi antara ibu dan bayi yang akan menciptakan kelekatan antara keduanya. Menurut Underdown mengemukakan bahwa salah satu sisi positif dalam pemberian pijat bayi adalah adanya interaksi atau hubungan ibu dengan bayi yang lebih intensif (Underdown A.2009)

Dalam penelitian lain yang melibatkan 52 bayi di Korea Selatan, dibuktikan bahwa interaksi ibu-anak yang melakukan pijat bayi lebih baik dibandingkan kelompok ibu yang tidak melakukan pijat bayi (Lee HK. 2006) Melalui pijat bayi, ibu diberi kesempatan untuk mengenal bayi lebih dekat, dan membangun kelekatan (bonding). Dengan demikian, ibu dapat mengerti dan menjadi lebih responsif terhadap kebutuhan bayi. (Gurol A, Polat S. 2012).

Stimulasi pijat memberikan rasa nyaman dan mengurangi atau mengalihkan rasa nyeri. Rasa nyaman ini diteruskan ke hipotalamus, sehingga kadar oksitosin dan serotinin meningkat. Serotonin diubah menjadi hormon melatonin oleh kelenjar epifisa otak pada malam hari. Melatonin digunakan terlibat dalam regulasi tidur, serotonin yang diberikan pada saat pijat bayi memiliki hubungan dengan peningkatan kualitas tidur bayi yang ditunjukkan dengan peningkatan jumlah durasi tidur bayi serta berkurangnya gangguan tidur bayi. (McGillion, F 2002)

Pijat bayi juga mempengaruhi sistem neuroimuno-endokrin. Stimulasi pijat memberikan rasa nyaman dan mengurangi atau mengalihkan rasa nyeri. Rasa nyaman ini diteruskan ke hipotalamus, sehingga kadar oksitosin dan serotinin meningkat. Serotonin terlibat dalam regulasi tidur, serotonin diubah menjadi hormon melatonin oleh kelenjar epifisa otak pada malam hari. Melatonin digunakan untuk menginduksi tidur sehingga seseorang akan mudah memulai tidur, mengurangi frekuensi terbangun pada malam hari dan mencegah bangun terlalu pagi.(Ferber SG, Laudon M, Kuint J, Wellper A, Zisapel N. 2002). Sejalan dengan penelitian Ferber at al, bayi yang di pijat menunjukkan tidur yang lebih teratur daripada kelompok kontrol. Serta tingkat melatonin yang dipijat pada bayi baru lahir lebih tinggi daripada kelompok kontrol, menunjukkan bahwa bayi yang baru lahir dengan melatonin yang lebih tinggi mengalami tidur yang lebih dalam $/$ restoratif. (Ferber SG, Laudon M, Kuint J, Weller A, Zisapel N. 2002) hal yang sama di ungkapkan pada penelitian Field kelompok pijat memiliki latensi yang lebih pendek untuk tidur, tidur lebih lama serta tidur lebih dalam. Pada gilirannya, jumlah pijat berkorelasi positif dengan total waktu tidur pada satu bulan untuk ibu dan bayi baru lahir dan perilaku tidur ibu dan bayi mereka berkorelasi positif.(Field. T, 2017)

\section{Perbedaan pijat dan SPA bayi terhadap peningkatan berat badan}

Penambahan berat badan pada kelompok pijat lebih besar dari pada kelompok SPA bayi dan terdapat perbedaan yang signifikan antar kedua kelompok. Penambahan rata- rata berat badan pada kelompok pijat bayi sebanyak $0,88 \mathrm{~kg} / \mathrm{bulan}$ sedangkan untuk kelompok pijat $0,66 \mathrm{~kg} / \mathrm{bulan}$, sedangkan penambahan berat badan normal pada bayi usia 3-6 bulan sebanyak 0,5-0,6 kg/bulan hal ini menunjukan bahwa pijat bayi dapat meningkatkan berat badan badan bayi secara optimal. Kurva pertumbuhan berat badan pada bayi laki-laki lebih besar dibandingkan dengan bayi perempuan.

Pada kelompok pijat sebagian besar adalah laki-laki $(56,7 \%)$ sedangkan pada kelompok SPA $(53,6 \%)$ adalah perempuan. Menurut penelitian Wulandari di Bogor, rata-rata kenaikan berat badan bayi laki-laki dari usia 0-6 bulan sebanyak 730.1 gram/bulan. Sedangkan rata-rata kenaikan berat badan pada bayi perempuan usia $0-6$ bulan sebanyak $634.6 \mathrm{gram} / \mathrm{bulan}$.(Wulandari A. 2007)

Pada kelompok pijat bayi diberikan pijat tiap hari selama 4 minggu sedangkan pada kelompok SPA bayi dilakukan 1 minggu sekali selama 4 minggu, adapun ketentuan pemberian SPA bayi tidak bisa dilakukan setiap hari. Terkait hal di atas, 
American Academy of Pediatrics (AAP) mengeluarkan pernyataan bahwa pada bayi di bawah 1 tahun, tujuan berendam (hidroterapi) adalah sebatas memberikan kesenangan dan meningkatkan ikatan antara bayi dan orangtua. Belajar berenang tidak direkomendasikan untuk anak di bawah 1 tahun.(AAP, 2015)

Perbedaan hidroterapi dan berenang adalah terapi air meliputi gerakan/latihan saat berada di dalam air yang suhu lebih hangat daripada suhu air di kolam renang biasa yaitu antara $35-36^{\circ} \mathrm{C}$. Sedangkan Berenang adalah upaya mencegah tenggelam saat berada dalam air. Pada tahun 2000, AAP mengeluarkan rekomendasi bahwa program renang pada anak sebaiknya dimulai setelah usia 4 tahun. Tanpa pelatihan khusus, bayi umumnya memperlihatkan gerakan renang rudimenter, seperti dog paddle saat berada dalam air. Namun, kemampuan berenang yang kompleks baru dapat dicapai ketika perkembangan motor anak mencapai tahap usia 4-5 tahun. Apabila diajari berenang lebih dini, waktu yang diperlukan untuk menguasai gerakan ternyata lebih lama dibandingkan dengan anak yang dilatih berenang di atas usia 4 tahun.(AAP, 2000)

Telah dijelaskan sebelumnya bahwa pada penelitian ini, semua responden diberikan ASI sebagai asupan nutrisinya. ASI adalah makanan yang terbaik bagi bayi pada 6 bulan pertama kehidupannya. Semua kebutuhan nutrisi yaitu protein, karbohidrat, lemak, vitamin dan mineral sudah tercukupi dari ASI. Menurut penelitian Asti di Yogyakarta, kenaikan berat badan bayi yang mendapatkan ASI lebih tinggi dibandingkan dengan kenaikan berat badan bayi yang mendapat ASI parsial.(Diego MA, Field T, Hernandez-Reif M. 2005)

Selain pemberian ASI pemijatan juga dapat mengoptimalkan peningkatan berat badan dengan cara meningkatkan tonus nervus vagus (nervus $X$ ) yang merangsang peningkatan produksi enzim penyerapan (gastrin, insulin) dan hormon pertumbuhan ( $\mathrm{GH}$ dan IGH-1) sehingga penyerapan disaluran pencernaan lebih baik. Hal ini akan menyebabkan bayi lebih mudah lapar sehingga periode menyusu lebih sering, dan ASI ibu akan bertambah produksinya karena dirangsang lebih sering oleh bayi melalui proses menyususi. Penyerapan yang lebih baik pada saluran cerna ini menyebabkan pertumbuhan bayi lebih baik salah satunya berat badan bayi bertambah dengan optimal.(S Ferius, Pustika Efar, Shirley Mansur, Hartono Gunardi. 2008)

Pada penelitian yang dilakukan oleh Nyoman melaporkan kenaikan berat badan bayi pada kelompok pijat lebih besar dari pada kelompok kontrol setelah 4 minggu dilakukan intervensi pijat (Dewi NN, Soetjiningsih, Prawirohartono PE. 2011) Menurut Dasuki dalam penelitiannya menemukan bahwa bayi yang lahir cukup bulan berusia 4 bulan mendapat terapi pijat selama 4 minggu memiliki kenaikan berat badan rata-rata lebih dari $33 \%$ dibandingkan kelompok kontrol. Sebagian besar penelitian pada studi meta analisis telah memberikan dampak yang positif pada perawatan pijat selama 4 minggu. (Field T. 2002)

Sejalan dengan penelitian Nyoman stimulasi pijat secara signifikan dapat meningkatkan berat badan (Dewi NN, 2011). Begitupun dengan penelitian Field $T$ dkk, terapi pijat pada bayi-bayi prematur dapat meningkatkan kadar insulin dan IGF-1. Penambahan berat badan berhubungan dengan peningkatan insulin dan IGF-1 (Kelmanson IA, Adulas El. 2006).

Pada pijat bayi juga diberikan minyak pada saat dilakukan pemijatan, berbagai minyak dapat digunakan untuk pemijatan. Di Indonesia minyak yang umum dipakai adalah minyak mineral, minyak kelapa, dan minyak telon. Minyak mineral lebih populer dikemas sebagai baby oil dengan berbagai merk. (Sankaranarayanan K, Mondkar JA, Chauhan MM, Mascarenhas BM, Mainkar AR, Salvi RY. 2005)

Pada pemberian minyak ini efek pijat tersebut lebih besar ketika menggunakan minyak, Para ahli menduga hal ini disebabkan oleh penyerapan minyak ke permukaan kulit.(Arora J, Kumar A, Ramji S. 2005).

Sejalan dengan penelitian Sankar di India, dampak positif minyak pijat diperkirakan didapat dari kemampuan nya membentuk lapisan di permukaan kulit yang mencegah terjadinya penguapan cairan tubuh sehingga suhu tubuh dapat dipertahankan. Termoregulasi yang baik tersebut dapat memicu pertumbuhan berat badan. (Sankaranarayanan $\mathrm{K}$ at. Al, 2005 )

Keterbatasan penelitian masih memiliki keterbatasan diantaranya adalah, Penelitian ini adalah desain quasi eksperimental sehingga meningkatkan kemungkinan bias antara kedua kelompok. SPA bayi hanya dilakukan 1-2 kali dalam seminggu.

\section{SIMPULAN DAN SARAN}

Berdasarkan hasil analisis dapat disimpulkan. Tidak terdapat perbedaan pengaruh antara pijat dan SPA bayi terhadap pola tidur bayi usia 3-5 bulan. Pengaruh pijat lebih baik dibandingkan dengan pengaruh SPA bayi terhadap peningkatan berat badan pada bayi usia 3-5 bulan. 


\section{SARAN}

Diperlukan penelitian lebih lanjut tentang pemberian SPA bayi yang dibarengi pijat bayi yang dilakukan secara teratur.

\section{DAFTAR PUSTAKA}

American Academy of Pediatrics. Policy Statement. Breastfeeding and the use of human milk. Pediatrics 2005;115;496-501 29.

American Academy of Pediatrics. Policy Statement. Breastfeeding and the use of human milk. Pediatrics. 2012;129;e827

American Academy of Pediatrics. Infant swimming. Diunduh dari https://www.healthychildren.org/English/ safety-prevention/at-play/Pages/InfantSwimming-Video.aspx. Diakses 13 Juli 2015. American Academy of Pediatrics, Committee on Sports Medicine and Fitness and Committee on Injury and Poison Prevention. Swimming programs for infants and toddlers. Pediatrics. 2000;105:868-70.

Arora J, Kumar A, Ramii S. Effect of oil massage on growth and neurobehavior in very low birth weight preterm neonates. Indian Pediatr.2005;42(11):1092-100.

Arthritis Research UK. What is hydrotherapy. Diunduh

dari: http://www.arthritisresearchuk.org/arthrit isinformation/therapies/hydrotherapy/what-ishydrotherapy.aspx.[di 13 Juli 2017]

Asti Norma, Ircham Machfoedz, Oktaviana Maharani. Perbedaan Kenaikan Berat Badan pada Bayi yang Mendapat ASI Eksklusif dengan ASI Parsial di Puskesmas Jetis Kota. Jurnal Ners dan Kebidanan Indonesia. 2015

Bennett C, Underdown A, Barlow J. Massage for promoting mental and physical health in typically developing infants under the age of six months (Review) : Cochrane Database of Systematic Reviews 2013 ; Issue 4. Art. No.: CD005038

Barros AJ, Matijasevich A, Santos IS, Halpern R. Child development in a birth cohort: effect of child stimulation is stronger in less educated mothers. Int J Epidemiol [Internet]. 2010 Feb 1;39(1):285-94.Available

from:http://www.ije.oxfordjournals.org/cgi/doi/ 10.1093/ije/dyp272

Dewi NN, Soetjiningsih, Prawirohartono PE. Effect of massage stimulation on weight gain in full term infants.Pediatric Indonesina. 2011;51:202-6
Dixy Febrianita Titi Pratama Putri, Perbedaan Hubungan antara Ibu Bekerja dan Ibu Rumah Tangga terhadap Tumbuh Kembang Anak Usia 2-5 Tahun. Mutiara Medika 2012; (12) 3: 143-149,

Dewi, K.A. Perbedaan Kualitas Stimulasi Ibu pada Anak Usia Pra Sekolah Ditinjau dari Status Bekerja dan Tidak Bekerja. Universitas Airlangga, Surabaya. 2010.

Dasuki MS. Pengaruh pijat bayi terhadap kenaikan berat badan bayi umur 4 bulan.Yogyakarta: Gadjah Mada University; 2003.

Diego MA, Field T, Hernandez-Reif M. Vagal activity, gastric motility, and weight gain in massaged preterm neonates. J Pediatr. 2005; 147(1):50-55. [PubMed: 16027695]

Faniyah Falah, Hardaningsih Galuh, Rahmadi F. Hubungan Antara Gangguan Tidur Dengan Perkembangan Batita. Media Medika Muda. 2015; (4): 732-744

Ferber SG, Kuint J, Weller A, Feldman R, Dollberg $\mathrm{S}$, Arbel $\mathrm{E}$, et al. Massage therapy by mothers and trained professionals enhances weight gain in preterm infants. Early Hum Dev 2002; 67: 37-45.

Field. T, Newborn Massage Therapy :International Journal of Pediatrics and Neonatal Health 2017; 1(2): 54-64

Ferber SG, Kuint J, Weller A, Feldman R, Dollberg $\mathrm{S}$, Arbel $\mathrm{E}$, et al. Massage therapy by mothers and trained professionals enhances weight gain in preterm infants. Early Hum Dev 2002; 67: 37-45.

Field T. Massage therapy. Complementary Alternat Med 2002;86:168-171.

Ferber SG, Laudon M, Kuint J, Weller A, Zisapel N. Massage therapy by mothers enhances the adjustment of circadian rhythms to the nocturnal period in full-term infants. Developmental and Behavioral Pediatrics 2002;23 (6):410-5

Gurol A, Polat S. The Effect Of baby massage on attachment between Mother their infant. Asian Nursing Research 6 (2012): 35-41

Gunardi H, Sutantio J. Baby SPA Sekedar tren atau terbukti bermanfaat. :23.07.2015;diunduh dari http://www.idai.or.id. [diakses 03 Maret 2017]

Jabraeile, M., Rasooly, AS., Farshi, MR., Malakouti, J. (2016). Effect of olive oil massage on weight gain in preterm infants: A randomized controlled clinical trial. Niger Med J., 57:1603.

Kemenkes RI. PMK No.8 Tahun 2014. Pelayanan Kesehatan SPA 
Kemenkes RI. Pedoman Pelaksanaan Stimulasi, Deteksi, dan Intervensi Dini Tumbuh Kembang Anak Ditingkat Pelayanan Kesehatan Dasar: Departemen Kesehatan RI, 2012:4-14.

Kelmanson IA, Adulas El. Massage therapy and sleep behaviour in infants born with low birth weight. Complement Ther Clin Pract 2006; 12: $200-205$

Lee HK. The effects of infant massage on weight, height, and mother-infant interaction. Journal of Korean Academy of Nursing. 2006 Dec;36(8):1331-9

McGillion,F. The Pineal Gland and The Ancient Art of latromathematica. Journal of Scientific Exploration 2002;(16)1: 19-38.

Paruthi, et al. Recommended amount of sleep for pediatric populations: A consensus statement of the American Academy of Sleep Medicine. Journal of Clinical Sleep Medicine 2016, 12(6), 786.

Ringwalt S. Developmental screening and assessment instruments with an emphasis on social and emotional development for young children ages birth through five. Chapel Hill NC: Nectac; 2008. 1-20

Roth, DE. The Relationship Massage Infant With Pattern And Sleep In Infants. journal of pediatric 2010. The University of Toledo Digital Repository

Sadeh A. A Brief Screening Questionnaire for Infant Sleep Problems: Validation and Findings for Internet Sample. PEDIATRICS 2004;113:570-577.

Sankaranarayanan K, Mondkar JA, Chauhan MM, Mascarenhas BM, Mainkar AR, Salvi RY. Oil massage in neonates: an open randomized controlled study of coconut versus mineral oil. Indian Pediatr 2005; 42: 877-884.

S Ferius, Pustika Efar, Shirley Mansur, Hartono Gunardi. Pengaruh Pijat Bayi Menggunakan Minyak Mineral atau Minyak Kelapa terhadap Kenaikan Berat Badan pada Nenonatus Aterm. Sari Pediatri , 2008;10:219-223

Sekartini R. Pola Tidur Pada Anak. 2015. Diunduh dari http://www.IDAl.or.id. [diakses 8 Mei 2017]

Soetjiningsih ,IG. N. Gde Ranuh. Tumbuh Kembang Anak, Jakarta: EGC 2013;98-350

UKK Tumbuh Kembang Pedsos. Modul Stimulasi Pijat Bayi :IDAI 2013;7-56

Underdown A, Barlow J, Chung V, Stewart-Brown S. Massage intervention for promoting mental and physical health in infants aged under six months (Review): Cochrane Database Syst Rev.2009

Vignochi CM, Teixeira PP, Nader SS. Effect of aquatic physical therapy on pain and state of sleep and wakefulness among stable preterm newborns in neonatal intensive care units. Rev Bras Fisioter. 2010 MayJun;14(3):214-20.

Whittingham,A \& Douglas, P. Optimizing Parent Infant Sleep From Birth to 6 Months: A New Paradigm. Infant Mental Health Journal 2014.1-9. C2014 Michigan Association for Infant Mental Health

Wulandari A. Pola pertumbuhan badan bayi usia 0 hingga 12 bulan. Departemen Biologi. Fakultas Matematika dan IImu pengetahuan Alam. Institut Pertanian Bogor 2007 